\title{
The achievement of simultaneity: kastom and place in Port Vila, Vanuatu
}

L'accomplissement de la simultanéité : kaston et lieu à Port-Vila, Vanuatu

\section{Benedicta Rousseau}

\section{OpenEdition}

Journals

\section{Electronic version}

URL: http://journals.openedition.org/jso/7692

DOI: $10.4000 /$ jso.7692

ISSN: $1760-7256$

Publisher

Société des océanistes

\section{Printed version}

Date of publication: 15 December 2017

Number of pages: $37-50$

ISSN: 0300-953x

\section{Electronic reference}

Benedicta Rousseau, "The achievement of simultaneity: kastom and place in Port Vila, Vanuatu", Journal de la Société des Océanistes [Online], 144-145 | 2017, Online since 15 December 2019, connection on 15 March 2021. URL: http://journals.openedition.org/jso/7692 ; DOI: https://doi.org/ $10.4000 /$ jso. 7692

\section{(c) (i) $\odot$}

Journal de la société des océanistes est mis à disposition selon les termes de la Licence Creative Commons Attribution - Pas d'Utilisation Commerciale - Pas de Modification 4.0 International. 


\section{The achievement of simultaneity: kastom and place in Port Vila, Vanuatu}

by

Benedicta ROUSSEAU*

\begin{abstract}
Historically, ni-Vanuatu in Port Vila have been portrayed as an un-grounded population, lacking the resources necessary to perpetuate a kastom-based, indigenous identity. Contrary to that approach, I demonstrate how the equation of kastom, place, and identity operates in town. Central to this is the existence of nongeographical communities focussed around shared island of origin, and what I term the "achievement of simultaneity" between town and island. I describe several urban kastom practices that work to achieve town/island simultaneity including recognition of chiefly authority, a dispute settlement exchange, and a ceremony to welcome a new member of a political party. Overall, I suggest that the persistence of island-based identity both illustrates and enables the existence of kastom in town.
\end{abstract}

KeYwords: Melanesia, chiefs, kastom, urban identity, simultaneity

While anthropologists have presented accounts of ni-Vanuatu cultures that emphasise primordial connection to place as axiomatic to identity formation (Bonnemaison, 1994; Jolly, 1994), niVanuatu in Port Vila have been portrayed as an - quite literally - un-grounded population, lacking the resources necessary to perpetuate a kastom-based, indigenous identity. While acknowledging that life in Vila is different to life in the islands, this article demonstrates how the equation of kastom, place and identity does operate in this alternative milieu. Central to this is

\section{RÉSUMÉ}

Par le passé, les ni-Vanuatu de Port-Vila ont été qualifiés de population déracinée sans ressources pour perpétuer une identité autochtone basée sur la coutume. Par contraste avec cette approche, je démontre comment l'équation kastom, lieu et identité fonctionne en ville. Au cour de cette équation, on trouve des communautés qui ne sont pas centrées géographiquement sur l'île d'origine, mais sur ce que jappelle "l'accomplissement de la simultanéité" entre ville et île. Je décris plusieurs pratiques urbaines de la kastom qui participent de cette simultanéité villeêlle et qui incluent la reconnaissance de l'autorité du chef, l'échange comme méthode de résolution des conflits et une cérémonie d'accueil d'un nouveau membre d'un parti politique. Globalement, je suggère que la persistance d'une identité insulaire illustre et permet l'existence de la kastom en ville.

Mots-clés : Mélanésie, chefs, kastom, identité urbaine, simultanéité

the existence of non-geographical communities centred around shared island of origin and what I term the "achievement of simultaneity" between town and island brought about in the context of urban kastom practices. In the first part of the article I examine the development and structuring of non-geographical communities in Vila, arguing against accounts that posit a necessary loss of island-based identity for the urban population. I then move on to show kastom in action in Vila, through ethnographic data on the recognition of chiefly authority, a reconciliation ceremony, and a 
ceremony to welcome a new member of a political party. These examples illustrate the way in which place provides the legitimative force necessary for kastom to have effect in town, and are considered in relation to Hirsch's (1995) argument relating to the achievement of temporal and spatial simultaneity, and Battaglia's (1995) analysis of "practical nostalgia". Overall, the article suggests that the persistence of island-based identity both illustrates and enables the existence of kastom in town. In Port Vila, the island - and thus, kastom - is given substance by jifs - town chiefs - who provide the objectification of these communities. Town and island co-exist in the figure of jifs and that simultaneity is mirrored in the logic informing kastom practices that take place in town.

\section{Port Vila}

While anthropological accounts of life in Vila have increased in recent years (Rousseau, 2004; Rawlings, 1999; Kraemer, 2013; Lind, 2011; Lindstrom, 2011; Rio, 2011; Cummings, 2013; Mitchell, 2003, 2011; Eriksen, 2009), prior to the late 1990s only Brown (1970), and the geographers Bedford (1973) and Haberkorn (1989, 1992) had focussed primarily on populations in town, while Tonkinson $(1968,1977)$ and Philibert $(1986,1988,1989)$ examined the peri-urban villages of Mele-Maat and Erakor respectively. Other accounts exist that provide "snapshots" of the town, coming predominantly from European settlers and, more recently, development-oriented sources. These descriptions encompass the shift in purpose of Port Vila from European administrative centre to its current role as the capital of the independent Republic of Vanuatu. This shift has involved a change in both the size and demographic make-up of Vila: from "colonial space" (Rodman, 1999) dominated by the European population in the earlier twentieth century, to overwhelmingly ni-Vanuatu at the start of the twenty-first century. ${ }^{1}$ However, in many accounts the indigenous population is ignored, or portrayed as being as foreign as the other residents. Urban space is not indigenous space; ni-Vanuatu are illequipped for life in town. These ideas continue through to the present day, especially in development literature, with ni-Vanuatu being assigned the roles of either "problem" or "victim". To some extent though they appear also in ni-Vanuatu's own images and discourses about town. While recent anthropological work seeks to redress im- balances in previous accounts by foregrounding the experiences of indigenous urban residents, it is necessary to recognise that many of those residents have not been and are not always keen to assume a solely urban identity themselves.

The European settlement at Port Vila came into being after earlier attempts to settle at Havannah Harbour on the north-west coast of Efate were abandoned due to a high incidence of malaria. In its early years, Vila served primarily as an entrepôt for traders, then, with the formalisation of the Condominium administration in 1906, it also housed the headquarters of the colonial powers. Despite its foundations as a European settlement though, Vila has rarely been the "white space" that the Condominium government promised (Rodman, 2001). An indication of the variety of inhabitants of Vila even in the earlier stages of colonialism can be found in the letters of "Asterisk", the pseudonym of Robert Fletcher, an Englishman resident in Vanuatu from 1912 to 1920 . He wrote:

"You should just see some of the things that haunt the 'beach' in Vila. Their only sustenance is absinthe and cigarettes, so fever takes them properly. They earn a precarious living by selling grog to Kanakas and gambling in the Chinese opium hovels. It is rarely that they venture out in the daylight, but if one does chance to see them the object lesson is salutary. I am sorry for some of the poor devils. They are all 'libérés' from Nouméa, not allowed to go back to France, unfitted for work, and with every man's hand against them [...]. Talking of Chinese, there are about 150 Orientals even in this little town - Javanese, Tonkinese, Japs, etc. They're a foul mob - the Tonkinese at any rate - but they can cook. They rob the wretched Kanakas right and left and teach them to smoke opium, which kills them off like flies. The wise Condominium Government places no restrictions on their coming and they are arriving by every steamer. The Tonkinese, of course, are French subjects, so they do get looked after a bit, but the rest can do what they like." (Asterisk, 1986 [1923]: 82-84)

This air of seediness and transience appears again in a 1939 assessment of Port Vila: A French visitor described it as ni port, ni ville, a town where:

"affluent planters seemed content to live in wooden huts roofed with corrugated iron, although they were a little ashamed of the ugliness of their town." (D’Obrenan, 1939, in Rodman, 1999: 486)

However, the type of interaction implied by Asterisk's account is not present in one of the earlier anthropological studies of the town. Brown's assessment of Vila emphasises the "plural" nature

1. It is important to state that this shift in population resulting in a ni-Vanuatu majority does not correspond with an equally major shift in economic power - "town" is still the centre of non-indigenous businesses which continue to control a disproportionate amount of the country's monetary wealth. In fact, the gap in wealth between indigenous ni-Vanuatu and expatriates has grown since independence. For instance, the ratio of expatriate to ni-Vanuatu income went from 12:1 in 1983 to $16: 1$ in 1989 . In that year expatriates earned $25 \%$ of national income, while accounting for less than $5 \%$ of the population (Connell and Lea, 1993: 52). 
of the town, "a medley of peoples who mix but do not combine" (1970: 95):

"[Vila] is a small multi-ethnic community [...]. [T]he ethnic categories are highly visible racially, linguistically, and culturally; the categories are also differentiated politically and economically; and mixing is selective and present in some institutional contexts only." (Brown, 1970: 96)

Brown presents an overview of the limited interaction between these "ethnic groups" in a variety of sporting and social events. Here is her description of one of the weekly dances held in varying locations around town:

\begin{abstract}
"Since most European young people over fifteen are away at school, those who attend the dances are mainly Vietnamese and Métisse girls and Métis boys of lower socio-economic position than the older French and British couples who attend. The boys and girls go separately, largely, in groups - the girls sitting at tables and the boys circulating among dance partners. New Hebrideans often watch from the street." (Brown, 1970: 114)
\end{abstract}

For Brown, New Hebrideans were the most peripheral group in Vila, and the least amount of mixing occurred between them and Europeans:

[A] few Europeans mix with Asians, Métis, and educated Islanders, ${ }^{3}$ who are an intermediate class, and some of these mix with New Hebrideans, but very few New Hebrideans associate with Europeans outside work and official activities.... [They] meet mainly as master and servant, employer and employee, professional and client, or administrator and subject." (Brown, 1970: 114)

What is ironic, yet un-noted by Brown, is that her own category of métis (people of mixed New Hebridean and European descent) constitutes the second largest "ethnic group" in her census of Vila (Brown, 1970: 104). But at no point is this most clearly embodied form of interaction acknowledged, or the possibility of "illicit" relations contained within the "official" contexts of interaction.

The marginalising of the indigenous population and its actions may be related to the preoccupation amongst social scientists at that time with "circular migration". Much research on Melanesian towns through the " 70 s adopted this as its primary mode of examining indigenous urban populations (May, 1977; Chapman and Prothero, 1985; Bonnemaison, 1985), viewing wage employment and urban residence as temporary, and the village as the primary site of identity. ${ }^{4}$ However, not all of these accounts acknowledge the limitations that were placed - both overtly and more subtly - on the possibility of permanent residence in Vila for ni-Vanuatu: until the late 1950s they were not allowed to stay in town without work and were subject to a curfew (Haberkorn, 1989); job opportunities were limited due to lack of formal education and the use of indentured labourers from south-east Asia; most available housing was controlled by employers and built only to accommodate "bachelors".

Bonnemaison (1985), for instance, seems to ignore these restrictions, instead developing an argument for the continuation of circular migration based on "cultural factors". He outlines the types of mobility that have occurred over the last century and relates these to "traditional" forms of movement, emphasising the relationship between territory and identity:

"Territory is lived as a space of safety but more deeply as a space of identity, and of communion with magical powers and local divinities." (Bonnemaison, 1985: 59)

He goes on to state that stamba or "roots" are necessary for life, meaning that trips outside of your territory had to be short and infrequent. He portrays "traditional mobility" as controlled, circumscribed and purposeful, and manages to equate forms of circular mobility practiced by niVanuatu during the period of European contact with these ideals. Through such an equation it becomes possible to see circular mobility as the culturally-based norm and likely to remain so as long as identity continues to rely on place:

"Even today a villager cannot live for too long outside his home place without alienating his identity and his territorial rights [...]. Mobility in Vanuatu is thus dominantly circular and shall remain so as long as the actual relationship between people and territory endures." (Bonnemaison, 1985: 77, 79)

As that example shows, permanent urban residence has been linked generally with a resultant change in the basis of identity for ni-Vanuatu. By the late 1980s the idea of permanent resi-

2. This description reminded me of scenes I witnessed in the main street of Vila on "cruise ship days" during my fieldwork in 2000-2001. The Mamu Bar in the centre of town would close its doors to "locals", catering to "tourists only" as the sign outside read (although, in my experience, anyone white and English-speaking could get in). It was not uncommon for the tourists' behaviour to turn rowdy, at which times ni-Vanuatu could be found watching from the street with a mix of curiosity and disdain (see also Mitchell, 2002 on what could be termed the ni-Vanuatu gaze). It is tempting to wonder if this may have been the same for the dances observed by Brown.

3. This category covers immigrants to the New Hebrides from other Pacific islands.

4. Though as Chapman and Prothero (1985) point out in their introduction, this approach was itself a move away from previous definitions of internal migration as strictly about permanent shifts in place of residence: "movements that involve moderately long durations of stay at a destination do not necessarily eliminate an eventual, and equally 'permanent' return to the places from which they originated" (1985: 1). 
dence in Vila was being accepted in academic literature (Haberkorn, 1989, 1992). However, an ensuing loss of island-based identity was again seen as a likely outcome, especially for the next generation of ni-Vanuatu being born and brought up in Vila:

“a large number of Paamese in Port Vila are second generation migrants and have to be regarded as urbanites [...]. Some of these second generation migrants may still have a stake in their parents' communities [...] [h] owever, a future 'return' by these young men and women to a "home" they have never known appears highly unlikely." (Haberkorn, 1992: 835)

A similar assessment is offered by Woi (1984), commenting on the Freswota housing development started in the early 1980s:

"whatever communal characteristics emerge from Fresh Wata $[s i c]$, the second generation of inhabitants there will not be a tribal ni-Vanuatu. Second generation Fresh Wata residents will come from mixed marriages and will be unable, in most cases, to speak the native language of either parent; they will have been brought up in a completely different environment and culture from that of a villager." (Woi, 1984: 64)

She goes on to predict the adoption of a Vila/ Efate-based identity by these young people:

"The Fresh Wata project responds to a very apparent need in Vila, but the implications for further generations are not good. All those who have been born and brought up in Vila town will, in their adult lives, argue with the 'real' Efate islanders that they also belong to Efate. Transplanted ni-Vanuatu will want the psychological security, social prestige, and the general public acceptance that Vila is their home." (Woi, 1984: 64)

\section{Non-geographical community and urban parallelism}

Looking back now on the statements of Bonnemaison (1985), Woi (1984) and Haberkorn (1992) they appear rather pre-emptory. Aspects of their arguments are relevant: there has been a reduction in vernacular language proficiency amongst the urban population; arguments have emerged between man Efate and those with other island identities - but these relate more to who has kastom authority over the land and people of Vila, rather than any vying for shared identity; and, while claims to land back in the islands can be hard to make from the position of a long-term Vila resident, that has not resulted in necessary return to the islands or a loss of island identity. This does not prevent the same tropes from being mobilised in the present in both official and informal "narratives of the crisis of urban growth" (Widmer, 2013: 150). Yet, attention to ethnographic evidence reveals the simplicity of the either/or scenario regarding place and identity in town in more recent decades. As Stern argues (this issue, pp. 117-130), the role of Vila in the nation's imaginary since independence may have diminished its previous inherent 'foreignness' for ni-Vanuatu, and I acknowledge the contribution this could make to the methods of belonging discussed in the rest of this chapter. Lindstrom's (2011) recent ethnography of "urbane" Tannese residents in Vila, for instance, provides ample evidence of island-based identity in action. In particular though, he addresses the issue of how connection is now maintained between town and the island. As he explains, connection is not an issue of individual identity alone - as implied in, for instance, Woi's analysis above. Rather, families develop strategies to ensure that rights to land can persist despite long term residence in town:

"Whereas a principal challenge for families in the 1970 s and 1980s was to entice young, sometimes feckless migrants to return back home, today now that large numbers of people have moved to Vila, migrants are instead concerned to protect and maintain their rights back on the island, particularly their claims to village house sites and garden lands. The predicament today is to persuade a few people to remain back on Tanna, rather than to secure migrant returns from town. Current family strategy is to leave at least one or two family members back home who will protect the rights and claims of their urban kin should these be locally contested." (Lindstrom, 2011: 261)

A range of practices supplement such strategic family dispersals, including fostering arrangements that span Vila and Tanna, regular holidays back on the island, and even "reverse remittances" from island to town in recognition of the expense of urban life (Lindstrom, 2011: 260-61). Additionally, kastom remains a relevant component of urban life. Lindstrom points to kava drinking circles in Tannese communities in Vila, the reinvigoration of "first shave" ceremonies for young men and associated exchanges, alongside the recognition of chiefly authority. Of particular relevance to my discussion is the "parallelism" inherent in these practices. Rather than these activities standing alone or even as urban instantiations of island ritual, there is a co-dependence between the two locations: exchange relationships between certain classes of kin are continued in town; support of the same churches and the John Frum movement enable town Tannese to "reflect and extend" the spiritual community of the village (Lindstrom, 2011: 259).

5. This assessment may be more accurate for Paama than for most of the islands in Vanuatu as it is small and suffers from a shortage of land for gardens. Its proximity to the volcano on the island of Lopevi has also led to problems, with the contamination of water supply and damage to gardens through ash fall (see Petrou and Connell, this issue, pp. 51-62). 


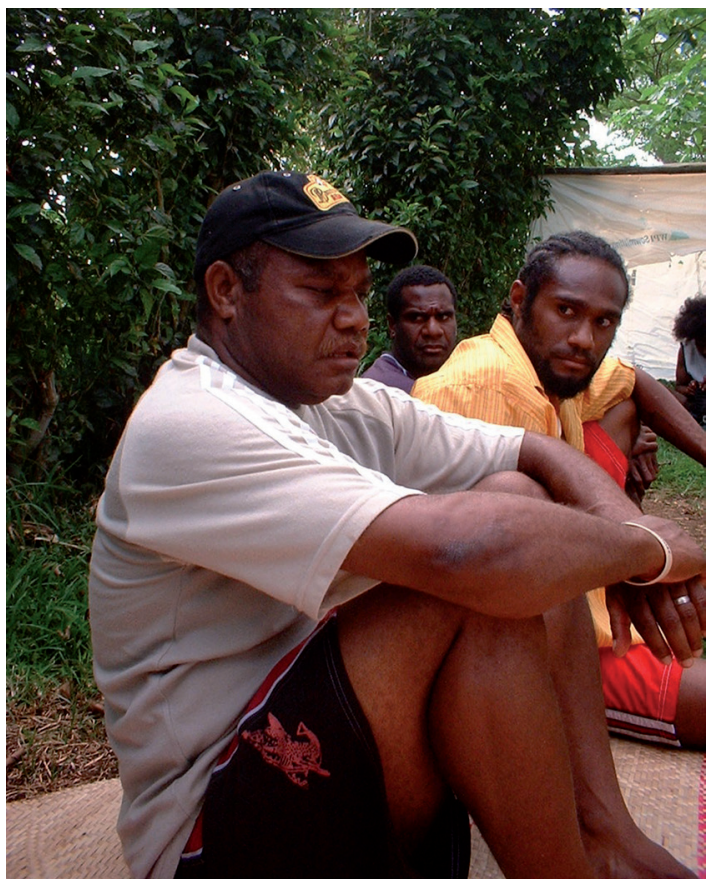

Picture 1. - Taon Jif (town chief) Jacob Kapere, Port Vila, 2006 (C) Lamont Lindstrom)

As those examples show, island-based identity continues to be a powerful social norm that operates as an organisational factor in areas such as residence, ritual, recreation, exchange, and the exercise of authority. Other identities - both individual and collective - are possible in Vila, such as those founded in work, schooling, sports and churches. Yet, I suggest that island of origin offers the key, continuous source of identity that is still most commonly used in town. Of course as length of residence in town extends across generations this may still change. The tenacity with which it holds though - in circumstances that involve much "mixing" of island kinship - speaks also to the flexibility of this form of identity. Some Vila residents are now able to form linkages within urban settings (such as school, work and church) by shifting emphasis amongst a number of possible island identities. As such, island identity is not necessarily perceived as an insoluble, singular link, nor naturalised as an unalterable component of all interactions. Alongside this malleable and gradated nature though, it is fair to say that most people in Vila will have a favoured or primary island affiliation that links them to a particular island-based community.

Broadly speaking, those in Vila who share an island of origin - or a particular area of an island - will at times operate as a community. For this, space is important but not necessarily in terms of constant geographical proximity. Rather, its continued existence depends on the opportunities for a community to re-establish relationships - both within the community and with those outside. This is done through a process I label "the achievement of simultaneity". This is two-fold, in that it incorporates the achievement of simultaneous understanding of the process and history of relationships between people, groups and places up to that point, as well as the simultaneous appearance of town and island. In Vila, the process occurs in various forms, but is defined by the objectification of simultaneity, achieved through such things as jifs [chiefs] and kastom resolution processes. In terms of kastom resolution, place provides the basis for the legitimate invocation of kastom, which assures the "correctness" of process. In such settings, urban communities - and jifs as the representation of that community - provide the objective instantiation of simultaneous place through their continued use of island-based identity. In the following sections, I outline this process in action through three examples: firstly, the links between place and chiefly authority in Vila; next through an ethnographic account of the resolution process followed by members of the Tannese and Tongoan communities in Vila; and lastly, through a ceremony held by the then-Prime Minister to welcome a new member into his political party.

\section{Jifs in Vila}

In interviews conducted through the Vanuatu Cultural Centre as part of its Juvenile Justice Project (Rousseau, 2003), young people living in Port Vila were asked if they had a jif where they live. Only one out of the ninety-three interviewees said they did not (Rousseau, 2003: 35). This indicates the ubiquity of jifs for the majority of Port Vila's population. They appear to be essential in the constitution of community - both in the sense that a jifs people make up a community, as well as a jif being necessary for people to function as a community. ${ }^{6}$

Jifs facilitate or enable correct procedure to be followed on public occasions and in interactions between families and communities in Vila. Yet life in town can necessitate improvisation in terms of finding who is equipped to occupy that role. Jifs do not constitute a coherent category in Vila: those working as jifs in town are not neces-

6. When I relayed this statistic to a Tannese jif in town, he expressed surprise that there was even one person who said they didn't have a jif. He saw this as a failing on the part of the jif as the burden is on them to both know and be known to all "their" people. While recognising this ubiquity though, it is important to note that other forms of interaction, authority, and social relations exist in town. But these are not relationships founded on or legitimated by kastom. For this reason, they cannot be relied on for the same purposes - such as the restoration of peaceful relations - and they may result in negative feelings, in particular the concept of "jealousy" (see also Wardlow, 2006: Chapter 1). Some types of relationships are hard to have in Port Vila. 
sarily "full jifs"; rather, they act as jif representatif [jif representatives]. This category has its roots in the early period of ni-Vanuatu residency in town, during which time predominantly younger men came for short periods of work. Due to their age, there would not always be a senior jif amongst them, in which case someone would be selected to act in that role temporarily. ${ }^{7}$ This practice continues today, but often on a more permanent basis. The term jif representatif does not necessarily imply that the holder does not have some title or rank himself. However, their authority to exercise control over a town population is legitimated by a jifly title in existence (and use) on their home island (Kernot and Sakita, 2008).

The idea of temporal and spatial simultaneity - or "parallelism" - has been discussed by Hirsch (1995) with reference to the Fuyuge in Papua New Guinea. He starts by drawing on Anderson's (1991) discussion of European practices of naming colonised land as:

“"new' versions of [...] 'old' toponyms in their lands of origin” (Anderson, 1991: 187, in Hirsch, 1995: 186)

Hirsch goes on to argue that similarities can be found between Anderson's analysis of colonising practices and naming practices of the Fuyuge:

"Among the Fuyuge, the similarity arises because place-names, as derived, for example, from the PNG capital of Port Moresby, exist parallel and coterminous with their place-name counterparts in the village - not as new versions, but as what we might call 'namesakes' (yasi). The parallelism is also meant to imply comparability, as in the European example. The example of an urban place-name in the village context does suggest that a desired redistribution of power is implicit in this practice, but it is a redistribution that is predicated on a different starting point from that of the Euro-American example." (Hirsch, 1995: 186)

In Vila, the presence of jifs exercising authority in someone else's name, or "namesake" jifs" councils in town, following the same law as their island parallels, imply a similar sense of simultaneity as that argued for by Hirsch. The idea of place as the legitimating basis of kastom ensures that the islands maintain their centrality and this is enabled by residents of Port Vila through their own (self-)naming practices - mi man Ambae; mi man Tanna. It is also supported by those in the islands, who frequently see their role as providers of correct knowledge to their dislocated population in town. ${ }^{8}$

Results of a survey conducted in 2001 revealed that for the majority of residents $(80 \%$ of interviewees) their jif exercised authority over a general island population rather than a geographically bounded one in terms of place of residence in town. In this way, they are jifs of people, rather than jifs of land. For this reason, though, the community's existence is not reinforced on a constant basis through visible evidence; simultaneity is not ensured. Hirsch outlines how,

"in ritual $(g a b)$ performed by the Fuyuge, the creation of this [temporal and spatial] simultaneity is conceptualized as an 'achievement' of holding things together [...] Men, women, and objects are thus simultaneously in the same space and at the same time for the enactment [...] of the ritual." (1995: 190)

For these non-geographical communities in Vila, meetings [miting] may well serve the purpose of the $g a b$, achieving the simultaneity that cannot be achieved or presumed through proximity. At the same time, "island" and "town" are made simultaneous through the use of kastom in the name of the island, and the legitimating force that it offers to the actions of jifs. This appears similar to a further strand of Hirsch's (1995) argument. However, it represents something of an inversion of his ethnographic example. In the Fuyuge village of Visi, a garden has been named Taurama "after" a commercial area of Port Moresby. Hirsch argues that this naming provides analogical opportunities for the Fuyuge:

\footnotetext{
"Taurama among the Fuyuge is less a fixed locale than a context from which analogies can be drawn. It is about bringing something into view; about creating a particular intentional space - a particular relation between foreground [the garden] [...] and horizon (Port Moresby). More generally, it is about displaying the capacity to hold things together in a particular sort of way." (Hirsch, 1995: 204)
}

For Hirsch, this practice is equated with the "local", as opposed to the "metropolitan" (to use his terms). For me, his statements regarding Taurama encapsulate the efficacious nature of island-based identification in Vila. ${ }^{9}$ Referring to the owner of the garden, Hirsch depicts him as:

\footnotetext{
"engaging in a cultural act that would be well recognized by his ancestors. It is through the analogies of
}

7. Similar patterns are found in Adams (1998), who provides an account of the perpetuation and adjustment of indigenous practices amongst Tannese labourers working on plantations in Queensland in the $19^{\text {th }}$ century.

8. This attitude was expressed on a number of occasions by island residents who I spoke with. When asked if there was kastom in town, they agreed that kastom practices did take place in town, such as weddings or funerals, but that town residents would often have to phone the island to check on aspects of procedure. In such cases, the telephone could be seen to offer a further route to simultaneity - potentially increased now by ready access to mobile phones (see Lipset, this issue, pp. 195-208). 9. As Hirsch says (1995: 193), the research on which this article was based did not include work with the Fuyuge living in Port Moresby. My fieldwork was the inverse of this, having spent only a small proportion of my time outside the "metropolitan" context, perhaps explaining my inverted reading of his statement. 
naming that he is attempting to "pull" that which is potentially 'out of time' and 'out of place' into a context where it anticipates the simultaneity achieved in the gab ritual." (1995: 203)

In the following section I will provide an account of a meeting held in Vila between members of the Tannese and Tongoan communities. This will illustrate the "pulling together" that occurs in this context, while foregrounding a further aspect of simultaneity that is touched upon by Hirsch. With reference to the simultaneity engendered by the $g a b$, he states that

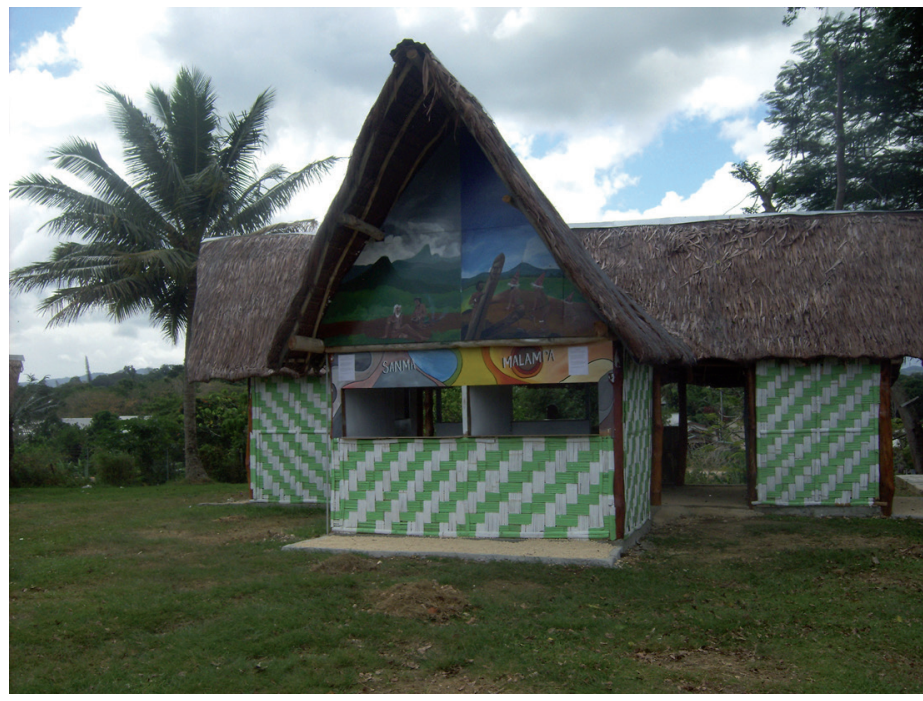

"upon completion of the ritual, this simultaneous spatial and temporal

FIgURE 2. - Chiefs nakamal kava bar, 2014 (C) Lamont Lindstrom) presence is abandoned, only to anticipate a similar ritual in a different locale in the future where such a simultaneity is again striven for." (Hirsch, 1995: 191)

In terms of the example that I present here, however, completion implies the desire to maintain the simultaneity that has been brought about through the meeting. The aim of the meeting is to draw together a coherent narrative of events that have led to this point of simultaneity, which can be seen to represent the desired form of relations between the two groups.

\section{Kastom dispute resolution in Vila}

In early 2001 a dispute occurred in Port Vila between Tannese and Tongoan residents of town. As the dispute was explained to me, a Tannese woman married to a Tongoan man suspected him of adultery. She had then gone and asked for help in dealing with this situation from her male Tannese relatives. Their reaction had been to launch an attack on the Tongoan area, damaging property and houses as well as attacking residents there. I later heard that there had been further retaliatory attacks by Tongoans on the original Tannese group involved. It was reported on the radio that at least two people had been hospitalised. Two days later, I was told that a meeting had been held at the Chiefs' Nakamal the previous day to sort matters out. However, this had dissolved into chaos, with further fighting taking place at the meeting itself, resulting in more casualties. It was implied to me that it was the Tannese who had initiated this, as

this was their way of sorting out disputes. On the following day, a further meeting was held to reconcile the two sides, and the following discussion draws on my attendance at that event.

The meeting brought together around 40-50 people from each of the two "sides" of the dispute, each of those groups then being referred to by the various speakers by their respective island names, Tanna and Tongoa. Also in attendance was a relatively sizable contingent of police (about 15). Next to them stood two jifs from each side - two of whom were dressed in "kastom clothing" of mats and headdress - along with a "master of ceremonies", as he was generally referred to. Further back, and to one side, sat representatives of the Malvatumauri (National Council of Chiefs) and the Port Vila Town Council of Chiefs (PVTCC). Others present included a few journalists, myself and a member of the Vanuatu Cultural Centre staff, present in our capacity as researchers for the Juvenile Justice Project (Rousseau, 2003).

The proceedings opened with the two sides moving towards each other, those from Tongoa carrying a variety of exchange items and two dead cows. The master of ceremonies spoke first, welcoming everyone on behalf of the Malvatumauri and the Port Vila Town Council of Chiefs, and telling everyone to sit down. He outlined the reason for today's meeting, but, rather than focussing on recent events, he talked first about a previous incident from 1987 involving Vilabased communities from Tanna and Tongoa ${ }^{10}$ :

"The two piles of food that you see here, one of these is for the incident that happened in 1987 - Tanna Tongoa, Tongoa Tanna - we came to the nakamal then to make peace, but Tongoa didn't make friends

10. I didn't ever clarify what exactly had occurred at that time - partly as it is not always appropriate to ask about matters that have been resolved. 
so trouble has happened again. We're meeting, now they have to rewind things back again. It's a perfectly normal thing, it's a normal thing that we fight; we make peace. But we didn't do that. So there are two cows and other food here: one is for 1987; the other is because we want to say sorry to our brothers and the jifs of Tanna."

This opening account destabilised my own understanding of the dispute and meeting as being connected to discreet events occurring over a period of a few days. It also presaged the tone of the following speeches, in which process was evaluated as much, if not more than action. This was exemplified in the words of one of the Tannese jifs. He outlined how the situation had escalated from a disagreement between 'two families' until it became a fight between Tongoa and Tanna. As he explained, two men started it, but these two weren't jifs. In kastom these men didn't have the right to call on others to go and attack people of a different island. Only a jif can send people to fight the people of another jif. A similar sentiment was expressed by Jacob Kapere, another of the Tannese jifs. For him, the meeting was one of the stages of making peace. He asserted that there are correct ways of sorting out problems. In this case, he was standing there as he has rank and had brought all his men with him ('ol boe blong mi) to make this ceremony ('mekem tabu ia') so that the bad feelings could end. He went on to talk about the necessity to ensure that when you make kastom, you make it properly. If this is not done problems will arise:

"when our children lose their way or go astray ('mestem rod), it's the fault of their elders. Today, we lost our way." 11

This statement was greeted with applause.

As suggested by both those speakers, the involvement of the jif was a key aspect in ensuring legitimacy to both disputes and their resolution. This point was expanded on by Jif Kapere as he went on to address the purpose of jifs in resolving disputes:

"If something happens, for example, a man 'stealing' a woman, this is a matter to be dealt with ' $j$ if to jif. If there is a fight, that doesn't mean that you do what you want without any respect for the jif - you go and tell your jif. Whatever you plan to do, go and see your jif."

The central role of the jif in determining process was reiterated again in the final part of his speech. Here, Jif Kapere addressed the actions of the police in response to the fight:
"When this problem happened, we [Kapere and Jif Douglas] told the head of police to take us around the nakamals of the two islands, Tanna and Tongoa, to tell them the jifs are here, they've started to solve the problem already. But I'm sorry to say that there has been a disturbance in our work, they haven't all respected our work. So I want to say to the senior police that if they want us to work together, we must respect each other."

These various statements put forward an ideal alignment of island-jif-community to ensure that disputes happen in the right way and are resolved in the right way. Problematic action occurs when community members do not act with reference to the jif as the objectificatory instance of the island in town. This viewpoint was expressed again by the final Tannese jif to speak, who was present at the meeting specifically to accept the apology for the 1987 incident. He thanked Tongoa for the kastom they had made today and mentioned the incomplete settlement of 1987, the effects of which have lingered up until the recent trouble on account of which they were meeting. He went on to address the issue of acting in alignment with your jif:

"When you come and argue with someone, you
come and hit someone, and you bring all your men
with you, you're using my tabu (sanction?). If you go
and murder someone or destroy a lot of property, this
is a reflection of my name (hemia i stap long nem blong
mi) - you are doing what I have told you should be
done. So this is one way in which jifs in Vanuatu have
power, but this is not such a good aspect of kastom."

He went on to emphasise that jifs must remind their people that when someone comes to argue with you, or fight with you, it's not good to gather up a posse of your own. As a result of this particular case, both Tanna and Tongoa now had bad names in town. This was met with applause. Again, this shows the objectificatory power of jifs: they are the encapsulation of their communities' actions, as well as being the sanction for violence and the vehicle through which reconciliation takes place - the jif as cipher.

The overriding concentration on "correct procedure" rather than punishment or atonement for incorrect actions led to emphasis on two issues in particular throughout the meeting: the fighting was initiated by people who didn't have that right; and secondly, that a proper settlement had never been completed for the 1987 incident. The first point was addressed by several of the speakers. The first Tannese jif to speak focussed on the escalation of matters from a disagreement between two families to a fully-fledged inter-island fight. His main criticism was that,

11. Aspects of Chief Jacob's speech reflect general characteristics of Tannese talk as discussed in detail by Lindstrom (1990), including the ways in which "roads" orient and control both action and the circulation of talk. 
in kastom, only jifs have the right to send their people to fight the people of another jif, and those involved in this dispute had not respected that right. This issue was returned to by the next Tannese speaker, who said that no action should be taken without first talking to your jif. Disagreements should be dealt with "jif-to-jif", and to do as those involved in the recent fight had done was to show a lack of respect for your jif. The final Tannese jif also covered similar ground in his speech. He emphasised that, in kastom, jifs have the ability to send people to fight, but that this action takes place in the jifs name, with their sanction. For this reason, initiating your own fight is wrong on two counts - it doesn't abide by kastom and it damages the reputation of your jif and, by extension, his people.

The incorporation of events from almost fifteen years earlier into the current settlement and its role in explaining why the recent fighting had taken place highlights a further aspect of the process of kastom. Reconciliation necessitates a sense of completion - the dispute had to be explained by and incorporated into a history of interaction between the two parties, resulting in a comprehensible and complete chain of events. As discussed above, this can be seen to represent a form of simultaneity. This is a simultaneity of historical understanding, which provides the basis of the meaning and intent of the future relationship between the two groups, and depends on the physical actuality of the meeting. In Hirsch's assessment of the gab, on completion simultaneity is 'abandoned' (1995: 191). In relation to this example, the achievement of simultaneity can be seen as an ideal not to be consciously abandoned. People may go "wan wan" after the meeting but the effect of what has taken place has changed them in relation to all other participants. A further example presented below indicates that this teleological drive towards simultaneity of historical understanding enabling future relationships is a more widespread feature of ceremonies in Vila. This example, however, involves politicians rather than $j i f s^{12}$. This, however, does not mean that it occurs outside of the same processes by which legitimate action is measured - kastom. Hence, I suggest, a similar process is followed to achieve simultaneity of various types.

\section{Kastom without $j$ ifs in Vila}

In late 2001 I attended a small ceremony at the house of a Vanua'aku Pati MP to mark the joining of the party by a former head of the Reserve Bank of Vanuatu. Also present was the Prime Minister and leader of the Vanua'aku Pati, Edward Natapei, his wife, friends and family of the hosts, and a number of party supporters from the neighbourhood. Such ceremonies are not unusual, generally involving either a high profile person (as in this case), or a jif who brings with him "his people's" votes. In this instance, the ceremonial aspect of the evening was relatively brief: the MP spoke first to welcome everyone, this was followed by a speech from the new member of the party, the Prime Minister responded to this speech, and the three then drank a shell of kava each. ${ }^{13}$ After this, others present who wanted to drank kava, and food and alcohol were served.

The speech given by the new party member explaining why he had decided to join the $\mathrm{Va}$ nua aku Pati focussed firstly on his personal history. He said which village and island he came from, which church his family had belonged to, and then talked about his father's affiliation with the Nagriamel movement in the 1970s. He recalled going to meetings of theirs as a child, as well as a demonstration they organised that took place on his island. From 1980 to 1992 he studied and lived in Papua New Guinea before returning to Vanuatu to take up the position at the Reserve Bank. At this point he spoke about reports that he was a supporter of the UMP (Union of Moderate Parties), historically the main rival to the Vanua'aku Pati. He said that this idea came from the fact that they were in government when he was appointed to the Reserve Bank, so it was assumed that he must be associated with them. But, he emphasised, he had never voted, and a major reason for being there today was to clear up the confusion and misinterpretations surrounding his political affiliation. His primary reasons for supporting the Vanua aku Pati were its strong leadership and faith in God, but he also mentioned his support for their policies, especially their promotion of transparency and good governance. He said he wasn't able to bring many voters with him to the party, but hoped he would be able to bring a few more people from his island in at the time of the party congress. In conclusion, he presented the Prime Minister with two mats from Ambae, first, in the common manner, denigrating their quality and condition before handing them over.

The Prime Minister's response to the speech started by stating the importance of every vote - "one person can make a difference". He also said that the party was not just gaining the new member's vote, but also his knowledge as a lawyer. Focussing

12. These are not necessarily discreet categories (see Lindstrom, 1997; Rousseau, 2004). At least one of the participants in the example I discuss did frequently make use of a chiefly name.

13. This is not strictly true - each person had someone to drink on their behalf as, for a variety of reasons, none of them drink kava. 
on the new member's previous association with Nagriamel, he said that they had been essentially the same as the Vanua'aku Pati at the time, with only their desired schedules for independence indicating any difference between them. He went on to say that there was also little difference now between any of the political parties in Vanuatu in terms of policy, so leadership and unity were the main indicators as to which would be most successful, thus backing up the new member's emphasis on leadership as a key factor in his decision to join.

I would argue that what is being accomplished in these speeches follows a pattern not dissimilar to that seen in the reconciliation between Tanna and Tongoa. In that example, what could be viewed as a series of events is turned into more a history of interaction, in which each part can be tied together in such a way as to make the present seem a logical - or even inevitable - conclusion. In this example the ceremony is framed almost as if a reconciliation is taking place. The new member appears to be not just joining the party but also atoning for his (supposed) past association with the UMP - even while denying that he had voted at all, his main purpose is to ensure that no misunderstandings exist. While involving a certain creativity in interpretation of pre-independence politics - namely the relationship between Nagriamel and the Vanua aku Pati - with the help of the Prime Minister, an integrative biography is formed, making the new member's current stance logical and complete.

As I have argued, the legitimation of kastom in Vila relies on place, and this is most readily objectified by jifs. In the example just given though, place was called into play in two other ways. Firstly, the man joining the Vanua'aku Pati started his speech by naming his village and island, thus "placing" himself. He also suggested that he might be able to bring more new members from his place, in this way connecting his joining the party to the village/ island. Secondly, when making a prestation to the Prime Minister to mark the ceremony, he chose mats from his home island of Ambae. Following on from Hirsch, I have argued that the legitimate use of kastom in Vila depends on making "town" and "island" simultaneous. The aspects I have highlighted from the ceremony indicate, that, even in the absence of jifs, place as the source of legitimate kastom can be present objectively;

\footnotetext{
"it is about bringing something into view; about creating... a particular relation between foreground... and horizon." (Hirsch, 1995: 204)
}

\section{The objectification of simultaneity}

Battaglia's (1995) notion of "practical nostalgia" is pertinent to the examples discussed here
- in relation to the changes wrought in those participating in the meeting, and the potential efficacy of their actions on the future. While acknowledging the warranted unease with which nostalgia is viewed by other scholars, she argues against the

"assumption that nostalgia has a categorically negative social value for indigenous actors." (Battaglia, 1995: 77)

She goes on to suggest that,

"Nostalgia may in fact be a vehicle of knowledge, rather than only a yearning for something lost. It may be practiced in diverse ways, where the issues for users become, on the one hand, the attachment of appropriate feelings toward their own histories, products, and capabilities, and on the other hand, their detachment from - and active resistance to - disempowering conditions of postcolonial life." (Battaglia, 1995: 77, emphasis in the original)

Her analysis focuses on a yam festival held by Trobrianders resident in Port Moresby in 1985. Using the festival and surrounding talk about yams, gardening, and life in town and "Home", she illustrates the 'transformative' properties of nostalgia. Rather than:

"a nostalgia that 'mourns for what is missing from the present, and thus creates representations of the past'." (Strathern, 1995: 111, in Battaglia, 1995: 78),

she puts forward:

"a practical or active nostalgia. [This] is transformative action with a connective purpose, and the affective and aesthetic quality of an indulgence. So that Home in this construction is the excess, the luxury of experiencing an attachment to sources..." (Battaglia, 1995: 78)

Her next point is particularly relevant to my arguments about the Tanna-Tongoa case - nostalgia's relationship to the future:

"It is in this variety that nostalgic connection may also be imagined toward a past object without necessarily being the enemy of unformulated future relationships. Indeed, nostalgia for a sense of future - for an experience, however imaginary, of possessing the means of controlling the future - may function as a powerful force for social reconnection." (Battaglia, 1995: 78)

The transformative power of nostalgia is reiterated in her conclusion, in which she asserts that:

"nostalgia has power to reposition within the present those who engage it." (Battaglia, 1995: 93) 
Her argument ties in with my contention that the achievement of a simultaneity of understanding through the process of the meeting or kastom ceremony results in a basis for future relations between those involved. Furthermore, the context in which this can occur relies on kastom, the use of which, in turn, relies on the establishment of temporal and spatial simultaneity between those participants and a place - "Home" - that provides legitimation of the kastom that is being called upon. The 'nostalgic connection' to "Home" thus enables the transformation of subjects and relations.

The role of objectification in this process is, importantly, distinct from "charges" of objectification levelled in particular at ni-Vanuatu politicians by anthropologists around the time of independence in relation to their political mobilisation of kastom (Keesing, 1982; Tonkinson, 1982; Philibert, 1986). By contrast, I emphasise the idea of objectification in relation to the effecting of change in a subject. I am influenced by Miller's (1987) interpretation of the term. He focuses on the possibilities of some form of transcendence through the externalisation involved in a 'creative act of differentiation' and subsequent reappropriation of the externalisation on the part of a subject. I would argue that this reading is applicable to what is being effected in the examples outlined in this article. In the Tanna-Tongoa case, a dispute was externalised through speech and actions, by which it was made into a logical whole that incorporated the history of interaction seen as necessary to the explanation and conclusion of the most recent events. Using the medium of kastom, the meeting could be said, in Miller's terms, to have created an externalised object that was then reappropriated in order to re-form the subjectivity of those involved.

The fact that Miller's approach is grounded in the area of material culture is also appropriate to these examples, in that it encourages the acknowledgement of the performative and material aspects of kastom - in particular, the objects that indicate the source of legitimation. In the cases cited above these include mats from Ambae, kastom clothing worn by the Tongoan jifs, even the kava drunk by the Prime Minister and others. However, I take this further to include the role of $j i f s$, and indeed the island-based communities of Vila that also appear as objects through the conscious externalisation of place as a source of legitimation.

The interplay of persons and places present and vital to life in Vila echoes Strathern's (1991) contention that, in Melanesia, "places travel". She suggests that a person's identity might be found in a variety of objects - shell valuables or contained in a bag - and it is these objects that travel, "are put on and taken off, are turned upside down." (Strathern, 1991: 117)

These are not "metonymic objects" though, which, as Stewart argues, are

"a kind of dispossession in that the presence of the object all the more radically speaks to its status as a mere substitution and to its subsequent distance from the self." (1991: 135)

\section{Rather,}

"[a] pearl shell is a place, we might say that walks between persons. All these things pass between people, decorate them and support them [...] Insofar as 'places' can appear now in one person and now in another, then it is the places that seem mobile. At least, Melanesians use locational devices to make this fact itself appear." (Strathern, 1991: 117)

In this way place and identity are linked within a person through objects, their use and consumption:

"The externalizing locations that ["we"?] might imagine as giving different perspectives on persons are here seen as attached to persons themselves. People appear to have different locations or positions on their own bodies, and thus different identities according to what they hold in their hands or where the food they eat came from. Things travel to and from them." (Strathern, 1991: 135)

Through this analytical lens, the distancing of identity and island-place previously argued for as a logical result of long-term residence in Vila (Woi, 1984; Bonnemaison, 1987) makes less sense. Instead, recognisably kastom ways of being are enabled through the possibility of place appearing in object form. Such an approach does not imply that this has to be a continuous process. Strathern leaves open the possibility that this is a discontinuous, punctuated process, which can then fit with ongoing alterations to the landscape of affiliation and affinity in Vila.

\section{REFERENCES}

AdAms Ronald, 1998. Experiencing Outside Worlds: Tannese Labour Recruitment in the Second Half of the Nineteenth Century, in V. Keck (ed.), Common Worlds and Single Lives: Constituting Knowledge in Pacific Societies, Oxford and New York, Berg, pp. 231250.

Anderson Benedict, 1991. Imagined communities: reflections on the origin and spread of nationalism, London, Verso. 
Battaglia Deborah, 1995. On Practical Nostalgia: Self-Prospecting among Urban Trobrianders, in D. Battaglia (ed.), Rhetorics of Self-Making, Berkeley, University of California Press, pp.77-96.

Bedford Richard D., 1973. New Hebridean Mobility: A study of circular migration, Canberra, ANU, RSPAS.

Bonnemaison Joël, 1985. Territorial control and mobility within niVanuatu societies, in M. Chapman and R. M. Prothero (eds), Circulation in population movement: Substance and concepts from the Melanesian case, London, Routledge and Kegan Paul, pp. 57-79.

-, 1994. The Tree and the Canoe: History and Ethnogeography of Tanna, Honolulu, University of Hawai'i Press.

Brown Paula G., 1970. Melanesian Mosaic: The Plural Community of Vila, in L. Plotnicov and A. Tuden (eds), Essays in Comparative Social Stratification, Pittsburgh, University of Pittsburgh Press, pp. 95-111.

Chanter Alaine, 2000. The Production of Social Disorder: The Example of the Daily Press in New Caledonia, in S. Dinnen and A. Ley, Reflections on Violence in Melanesia, Canberra, Hawkins Press/Asia Pacific Press, pp. 65-79.

Chapman Murray and R. Mansell Prothero (eds), 1985. Circulation in population movement: Substance and concepts from the Melanesian case, London, Routledge and Kegan Paul.

Connell John and J.P. Lea, 1993. Pacific 2010: Planning the Future: Melanesian cities in 2010, Canberra, ANu, National Centre for Development Studies.

Cummings Maggie, 2013. Looking Good: The Cultural Politics of the Island Dress for Young Women in Vanuatu, The Contemporary Pacific 25 (1), pp. 33-65.

ERIKSEN Annelin, 2009. Healing the nation: In search of unity through the Holy Spirit in Vanuatu, Social Analysis 53 (1), pp. 67-81.

Fletcher Robert James, 1986 [1923]. Isles of Illusion, London, Century.

Foster Robert (ed.), 1995. Nation Making: Emergent Identities in Postcolonial Melanesia, Ann Arbor, University of Michigan Press.

Gewertz Deborah B. and Fred K. Errington, 1999. Emerging Class in Papua New Guinea: The Telling of Difference, Cambridge, Cambridge University Press.

Haberkorn Gerald, 1989. Port Vila: Transit Station or Final Stop? Recent Developments in
ni-Vanuatu Population Mobility, Canberra, ANU, National Centre for Development Studies.

—, 1992. Temporary Versus Permanent Population Mobility in Melanesia: A Case Study from Vanuatu, International Migration Review 26 (3), pp. 806-842.

Hirsch Eric, 1995. Local Persons, Metropolitan Names: Contending Forms of Simultaneity among the Fuyuge, Papua New Guinea, in R. Foster, Nation Making: Emergent Identities in Postcolonial Melanesia, Ann Arbor, University of Michigan Press, pp. 185-206.

Jolly Margaret, 1994. Women of the Place: kastom, colonialism and gender in Vanuatu, Reading and Chur, Harwood Academic Press.

-, 1999. Another Time, Another Place, Oceania 69 (4), pp. 282-299.

KeEsing Roger M., 1982. Kastom in Melanesia: an overview, Mankind 13 (4), pp, 297-301.

Kernot Sarah and Lai Sakita, 2008. The Role of Chiefs in Peacebuilding in Port Vila, State, Society and Governance in Melanesia, Discussion Paper 2008/4.

Kraemer Daniela, 2013. Planting roots, making place: An ethnography of young men in Port Vila, Vanuatu, Doctoral dissertation, The London School of Economics and Political Science (LSE).

LIND Craig, 2011. Placing Paamese: Locating concerns with place, gender and movement in Vanuatu, Doctoral dissertation, University of St Andrews.

Lindstrom Lamont, 1990. Knowledge and power in a South Pacific society, Washington DC, Smithsonian Institution Press.

- 1997. Chiefs in Vanuatu today, in G. M. White and L. Lindstrom (eds), Chiefs Today: Traditional Pacific leadership and the postcolonial state, Stanford, Stanford University Press, pp. 211-228.

-, 2011. Urbane Tannese: Local Perspectives on Settlement Life in Port Vila, Journal de la Société des Océanistes 133, pp. 255-266 (https://jso.revues.org/6461).

May Ron J. (ed.), 1977. Change and Movement: Readings on Internal Migration in Papua New Guinea, Canberra, ANU Press.

Miller Daniel, 1987. Material culture and mass consumption, Oxford, Blackwell.

Mitchell Jean, 2000. Violence as continuity: violence as rupture - narratives from an urban settlement in Vanuatu, in S. Dinnen and A. Ley, Reflections on Violence in Melanesia, 
Canberra, Hawkins Press/Asia Pacific Press, pp. 189-208.

-, 2002. Roads, Restlessness, and Relationships: An Urban Settlement in Postcolonial Vanuatu, $\mathrm{PhD}$ thesis, University of York, Canada.

-, 2011. 'Operation Restore Public Hope': Youth and the Magic of Modernity in Vanuatu, Oceania 81 (1), pp.36-50.

Philibert Jean-Marc, i986. The Politics of Tradition: Toward a Generic Culture in Vanuatu, Mankind 16 (1), pp. 1-12.

—, 1988. Women's Work: A Case Study of Proletarianization of Peri-Urban Villagers in Vanuatu, Oceania 58 (3), pp. 161-175.

—, 1989. Consuming Culture: A study of simple commodity consumption, in $\mathrm{H}$. Rutz and B. Orslove, The Social Economy of Consumption: Monographs in Economic Anthropology, Landham MD, University of America, pp. 59-84.

Rawlings Greg, 1999. Foundations of Urbanisation: Port Vila Town and Pango Village, Vanuatu, Oceania 70 (1), pp. 72-86.

—, 2002. "Once there was a garden, now there is a swimming pool": inequality, labour and land in Pango, a peri-urban village in Vanuatu, $\mathrm{PhD}$ thesis, Australian National University.

Rio Knut M., 2011. Policing the holy nation: The state and righteous violence in Vanuatu, Oceania 81 (1), pp. 51-71.

Rodman Margaret C., 1999. Portentous splendour: Building the condominium of the New Hebrides, History and Anthropology 11 (4), pp. 479-514.

-, 2001. Houses far from home: British colonial space in the New Hebrides, Honolulu, University of Hawai'i Press.
Rousseau Benedicta (ed.), 2003. The Report of the Juvenile Justice Project: A resource on juvenile justice and kastom law in Vanuatu, Port Vila, Vanuatu Cultural Centre.

-, 2004. The Achievement of simultaneity: kastom in contemporary Vanuatu, PhD thesis, University of Cambridge.

STEWART Susan, 1993. On longing: narratives of the miniature, the gigantic, the souvenir, the collection, Durham, Duke University Press.

Storey Donovan, 1998. Managing urban decline? Urban governance in the context of Port Vila, Vanuatu, Development Bulletin 45, pp. 32-35.

Strathern Marilyn, 1991. Partial Connections, Savage Md., Rowman and Littlefield.

Tonkinson Robert, 1968. Maat village, Efate: a relocated community in the New Hebrides, Eugene, Oregon, Department of Anthropology, University of Oregon.

—, 1977. The Exploitation of Ambiguity: A New Hebrides Case, in M. D. Lieber (ed.), Exiles and Migrants in Oceania, Honolulu, The University of Hawai'i Press, pp. 269-295.

- 1982. National Identity and the problem of kastom in Vanuatu, Mankind 13 (4), pp. 306-315.

WardLow Holley, 2006. Wayward women: Sexuality and agency in a New Guinea society, Berkeley, University of California Press.

Widmer Alexandra 2013. Diversity as valued and troubled: social identities and demographic categories in understandings of rapid urban growth in Vanuatu, Anthropology \& medicine 20 (2), pp. 142-159.

WoI Nancy, 1984. Fresh Wata Estate in Port Vila, in P. Larmour (ed.), Land Tenure in Vanuatu, Suva, University of the South Pacific, Institute of Pacific Studies, pp. 62-64. 


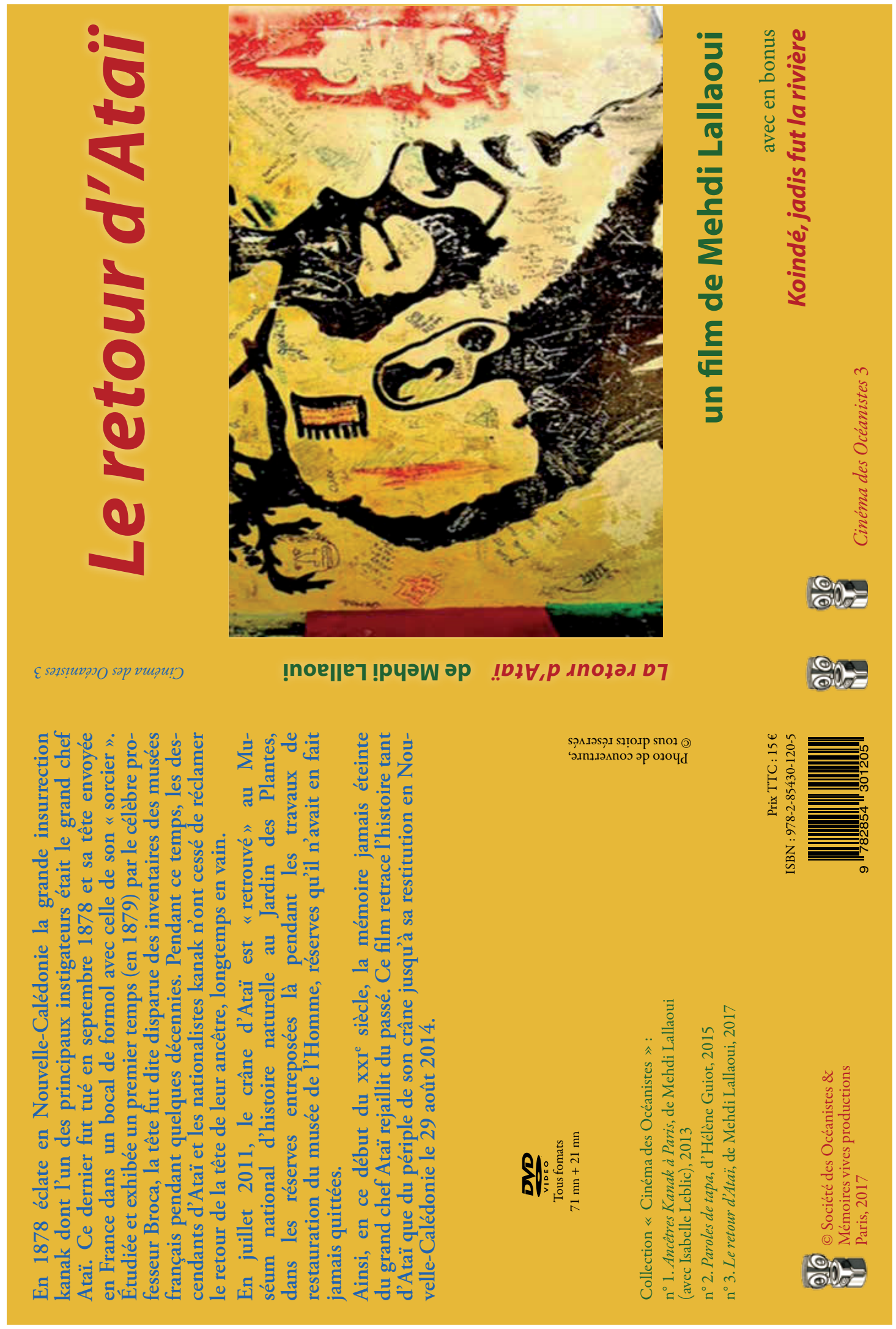

À commander sur http://www.oceanistes.org/oceanie/boutique/le-retour-datai/ ou disponible à la librairie du musée du quai Branly 